\title{
Are pregnancy complications increased in poor responders?
}

\section{Ovaryen stimulasyona kötü yanıt veren hastalarda gebelik komplikasyonlan artmıs midır?}

\author{
Huriye Ayşe Parlakgümüş, Bülent Haydardedeoğlu, Erhan Şimşek, Tayfun Çok, Cem Yalçınkaya, \\ Cantekin İskender, Esra Bulgan Kılıçdağ \\ Department of Obstetrics and Gynecology, School of Medicine, Baskent University, Ankara, Turkey
}

\section{Abstract}

Objective: To investigate whether pregnancy complications are increased in poor responders to ovarian stimulation in IVF treatment.

Material and Methods: We reviewed the antenatal follow up and birth records of 26 poor responders to ovarian stimulation and 125 normoresponder patients in an IVF program.

Results: Eighty nine (71.2\%) of the normoresponders and 22 (84.6\%) of the poor responders had no pregnancy complications. Gestational diabetes was present in 18 (14.4\%) of the normoresponders and $3(11.5 \%)$ of the poor responders. Seven of the normoresponders had placenta previa (5.6\%). Two of the normoresponders (1.6\%) had pregnancy induced hypertension. Two (1.6\%) of the normoresponders had preeclampsia. One patient from each group had fetal anomaly (3.8\% for poor responders vs. $0.8 \%$ for normoresponders). Cholestasis of pregnancy was present in two of the normoresponders (1.6\%) and the 2 patients (7.7\%) who delivered prematurely also belonged to this group. Conclusion: Our results revealed that pregnancy complications were not increased in patients with a reduced ovarian reserve when compared to their age matched counterparts.

(J Turkish-German Gynecol Assoc 2011; 12: 1-3)

Key words: Pregnancy complications, poor ovarian reserve, IVF, poor response

Received: 13 August, 2010

Accepted: 22 November, 2010
Özet

Amaç: IVF tedavisinde ovaryen stimülasyona kötü yanı veren hastalarda gebelik komplikasyonlarının artıp artmadığını incelemek.

Gereç ve Yöntemler: IVF tedavisinde ovaryen stimülasyona kötü yanit veren 26 hastanın ve iyi yanıt veren 125 hastanın antenatal izlem ve doğum kayıtları retrospektif olarak incelendi.

Bulgular: İyi yanıt veren hastaların 89'unda (\%71.2) ve kötü yanıt veren hastaların 22'sinde (\%84.6) herhangi bir gebelik komplikasyonu olmadı. İyi yanıt verenlerin 18'inde (\%14.4) ve kötü yanıt verenlerin 3 'ünde (\%11.5)gestasyonel diyabet vardı. İi yanıt veren hastaların 7 'sinde (\%5.6) plasenta previa, 2'sinde (\%1.6) gebeliğe bağlı hipertansiyon, 2'sinde( \%1.6) preeklampsi vardı. Her gruptan birer hastada fetal anomali mevcuttu ( Kötü yanıt veren grupta \%3.8, iyi yanıt veren grupta \%0.8). İyi vanıt veren gruptaki hastaların 2'sinde (\%1.6) gebelik kolastazı vardı ve erken doğum yapan 2 hasta (\%7.7) da bu grupta bulunuyordu.

Sonuç: Bu çalışmanın sonuçlarına göre yaşıtlarına kıyasla kötü over rezervi olan hastalarda gebelik komplikasyonları artmamıştır.

(J Turkish-German Gynecol Assoc 2011; 12: 1-3)

Anahtar kelimeler: Gebelik komplikasyonları, kötü over rezervi, IVF, kötü yanıt

Geliş Tarihi: 13 Ağustos 2010

Kabul Tarihi: 22 Kasım 2010

eases complicating pregnancy. Preterm labor and low birth weight babies and unexplained still birth are increased in elderly gravidas $(1,4)$.

The question of whether this increased incidence of complications in women of advanced age because of ageing of the organism itself or ageing of the ovarian follicles needs to be investigated. Chronological age of the ovaries is not always equivalent to the biological age. Approximately 10\% of the women have a diminished ovarian reserve and accelerated ovarian ageing when compared to their age matched counterparts. Chromosomal abnormalities and abortions are proven to be increased in women with advanced ovarian age in the previous studies (5-7). However an impact of ageing of the oocytes on pregnancy complications has not been investigated. In this study we aimed to determine whether pregnancy complications are increased in women with advanced ovarian ageing. 


\section{Materials and Methods}

This retrospective study was conducted at Baskent University from December 2004 to April 2008. We reviewed the antenatal follow up and birth records of 26 poor responder and 125 normoresponder patients. Twenty six poor responder women who had undertaken IVF/ICSI cycle treatment and were successfully delivered in Baskent University were eligible for this study. Patients from whom less than or equal to 6 oocytes were collected at the oocyte retrieval, which consisted of germinal vesicle and metaphase I, II oocytes, despite a total gonadotrophin dose over 3000 IU used, were defined as poor responders. Oral contraceptive plus microdose flare-up protocol and GnRH Antagonist protocol were performed on all poor responder women. Patients from whom more than 6 oocytes were collected at the oocyte retrieval, which consisted of germinal vesicle and metaphase I, II oocytes, with a gonadotrophin dose of less than 3000 IU used, were defined as normoresponders. Only long GnRH agonist protocol has been performed on normoresponder 125 women. Women whose gestational follow-up and their deliveries were completed at Baskent University were eligible for this study as well. Exclusion criterias of this retrospective study were pregnancies conceived spontaneously, pregnancies after spontaneous and induced embryo reduction, and multiple pregnancies. Multiple pregnancies were excluded to avoid the confounding effect of increased complications attributed to them. According to our clinical approach, long GnRH agonist protocol is the first choice for expected normoresponder patients.

In this retrospective analysis, we aimed to distinguish the prenatal outcomes of normoresponder women and poor responder women, who had undertaken the IVF/ICSI program.

\section{Statistical analysis}

Data were expressed as means \pm standard deviation (SD) and analyzed with Student's t test, Chi-square test, and MannWhitney two sample test (unpaired, nonparametric). $\mathrm{p}<0.05$ was considered significant. SPSS for Windows (version 16.0; SPSS, Inc., Chicago, IL) was used for statistical analyses.

\section{Results}

Demographic characteristics of the patients are given in Table 1. A total of 113 (74.8\%) patients, of whom 93 (74.4\%) were from the normoresponder group and 20 (76.9\%) were from the poor responder group, did not have any pregnancy complications. Eighteen patients (14.4\%) from the normoresponder group and $3(11.5 \%)$ patients from the poor responder group had gestational diabetes. Seven patients from the normoresponder had placenta previa (5.6\%). Two patients from the normoresponder (1.6\%) group had pregnancy induced hypertension. Two patients (1.6\%) from the normoresponder group had preeclampsia. One patient from each group had fetal anomaly (3.8\% for poor responders vs. $0.8 \%$ for normoresponders). Two patients from the normoresponder (1.6\%) group had cholestasis. Two patients from the poor responder group were delivered prematurely (7.6\%). There was no preterm labor in the normoresponder group.
Table 1. Demographic characteristics of the patient and data regarding delivery. Data are expressed as means \pm standard deviations

\begin{tabular}{|l|c|c|l|}
\hline & $\begin{array}{c}\text { Normoresponder } \\
(\mathbf{n = 1 2 5 )}\end{array}$ & $\begin{array}{c}\text { Poor responders } \\
(\mathbf{n = 2 6 )}\end{array}$ & $\mathbf{p}$ \\
\hline Age (year) & $30.68 \pm 5.28$ & $32.50 \pm 4.51$ & NS \\
\hline BMI $\left(\mathrm{kg} / \mathrm{m}^{2}\right)$ & $25.89 \pm 4.12$ & $26.13 \pm 4.54$ & NS \\
\hline $\begin{array}{l}\text { Gestational } \\
\text { week at delivery }\end{array}$ & $38.00 \pm 0.81$ & $37.35 \pm 2.16$ & NS \\
\hline $\begin{array}{l}\text { Birth weight } \\
\text { (grams) }\end{array}$ & $3243 \pm 421$ & $3074 \pm 620$ & NS \\
\hline \multicolumn{2}{|l|}{ BMI: Body mass index, NS: Non-significant } & \\
\hline
\end{tabular}

\section{Discussion}

Our results revealed that pregnancy complications were not increased in patients with a reduced ovarian reserve when compared to their age matched counterparts. More than two thirds of the patients had uneventful pregnancies. Gestational diabetes was the most common disease complicating pregnancy. Incidence was similar in both the study and control groups (14.4 vs. $11.8 \%)$. In the literature the incidence of gestational diabetes varies between $1.4 \%$ and $14 \%$ depending on the characteristics of the population studied and the screening method (8). Placenta previa was the second most common complication. Romunstad et al. compared the pregnancies which are conceived spontaneously and via ART in the same mother and reported a three fold increase in placenta previa in IVF pregnancies (9). The incidences of pregnancy induced hypertension and preeclampsia in both groups were somewhat lower than the expected rates of $6 \%$ for gestational hypertension (10) and $12-22 \%$ for preeclampsia (11). This may be explained by the small size of the groups, mean age of the groups or the singleton pregnancies selected for the study. Preeclampsia is more common in women below 18 and over 35 years of age and in multiple pregnancies. The mean age of the patients was 30.6 years and 32.5 years for normoresponders and poor responders respectively, which may have contributed to the low incidence of hypertensive diseases. The major congenital anomaly rate is reported to be $2.91 \%$. In this study it was lower than the expected rate for the normoresponder group. However, this may be due to the small sample size. Two patients from the normoresponder (1.6\%) group had cholestasis. The incidence of intrahepatic cholestasis of pregnancy is reported to be 0.1 $15.6 \%$ (12). The incidence of prematurity was $7.7 \%$ for the normoresponders (Table2). This is lower than the incidence of $13.8 \%-14.1 \%$ reported in the literature (13).

In conclusion, the biological age of the organism seems to determine the outcome of pregnancy. Currently there are no studies on the effects of ovarian ageing on pregnancy in patients aged $<35$ years. However, there have been some studies on pregnancy outcomes in patients aged $\geq 35$ years and receiving young donor oocytes. Excellent pregnancy outcomes are reported in these pregnancies $(14,15)$. Porreco et al. compared 
Table 2. Pregnancy complications of poor responder and normoresponder women. Data are expressed as percentages (\%)

\begin{tabular}{|l|c|c|c|c|}
\hline & $\begin{array}{c}\text { Normoresponders } \\
(\mathbf{n = 1 2 5 )}(\mathbf{\%})\end{array}$ & $\begin{array}{c}\text { Poor responders } \\
(\mathbf{n = 2 6 )}(\mathbf{\%})\end{array}$ & $\begin{array}{c}\text { Total } \\
(\mathbf{n}=\mathbf{1 5 1})(\%)\end{array}$ & $\mathbf{p}$ \\
\hline No complication & $93(74.4 \%)$ & $20(76.9 \%)$ & $113(74.8 \%)$ & NS \\
\hline Gestational diabetes & $18(14.4 \%)$ & $3(11.5 \%)$ & $21(13.9 \%)$ & NS \\
\hline Placenta previa & $7(5.6 \%)$ & - & $7(4.6 \%)$ & - \\
\hline Pregnancy induced hypertension & $2(1.6 \%)$ & - & $2(1.3 \%)$ & - \\
\hline Preeclampsia & $2(1.6 \%)$ & - & $2(1.3 \%)$ & - \\
\hline Fetal anomaly & $1(0.8 \%)$ & $1(3.8 \%)$ & $2(1.3 \%)$ & NS \\
\hline Cholestasis of pregnancy & $2(1.6 \%)$ & - & $2(1.3 \%)$ & - \\
\hline Preterm labor & - & $2(7.6 \%)$ & $2(1.3 \%)$ & - \\
\hline
\end{tabular}

pregnancies of women older than 45 years who had pregnancies from an oocyte donation cycle with spontaneous pregnancies of women younger than 36 years old. The gamete age was similar in both groups. They reported that mature women over 45 years conceiving largely through ART with donor eggs can expect newborn outcomes similar to younger women cared for in the same setting of a high-risk maternal-fetal practice (16). Because IVF pregnancies themselves are already at high risk for perinatal complications, we included IVF patients into both the study and the control groups. The limitation of this study is the small size of the poor responder group. In our center, $12.7 \%$ of the ART cycles were the poor responder's cycles, which is consistent with the literature. In fact, it has been reported to be $9-26 \%$ (17). The low rate of pregnancy, the live birth rate and the high miscarriage rate in poor responder patients may be due to the poor quality of oocytes. Because of the high abortion rates in poor responders, the number of women reaching the first trimester screening is fewer. Besides, only the pregnant women who would have singleton babies were enrolled to avoid the possible confounding effect of multifetal pregnancy on serum markers. Our center is also a reference center to which patients from the neighboring cities present for ART. In addition, most of the patients, when they become pregnant, return home where they attend antenatal care and deliver. For these reasons, a high number of the scheduled poor responder patients did not come to the first trimester screening. Therefore, data of only 26 poor response patients screened in the first trimester were available. All the above mentioned factors caused a small size of the poor responders. This study may be considered a pilot study and a larger study can yield more accurate results.

\section{Conflict of interest}

None declared.

\section{References}

1. Cleary-Goldman J, Malone FD, Vidaver J et al. FASTER Consortium: Impact of Maternal Age on Obstetric Outcome. Obstet Gynecol 2005; 105: 983-90. [CrossRef]

2. Prysak M, Lorenz RP, Kisly A. Pregnancy outcome in nulliparous women 35 years and older. Obstet Gynecol 1995; 85: 65-70. [CrossRef]
3. Newcomb WW, Rodriguez M, Johnson JW. Reproduction in the older gravida. A literature review. J Reprod Med 1991; 36: 839-45.

4. Franz MB, Husslein PW: Obstetrical management of the older gravida. Womens Health 2010; 6: 463-8. [CrossRef]

5. Freeman SB, Yang Q, Allran K, Taft LF, Sherman SL. Women with a reduced ovarian complement may have an increased risk for a child with Down syndrome. Am J Hum Genet 2000; 66: 1680-3. [CrossRef]

6. van Montfrans JM, van Hooff MHA, Martens $f$ and Lambalk CB. Basal FSH, estradiol and inhibin B concentrations in women with a previous Down's syndrome affected pregnancy. Hum Reprod 2002; 17: 44-7. [CrossRef]

7. Nasseri A, Mukherjee T, Grifo JA, Noyes N, Krey L and Copperman AB. Elevated day 3 serum follicle stimulating hormone and/or estradiol may predict fetal aneuploidy, Fertil Steril 1999; 71: 715-8. [CrossRef]

8. Hadden DR. Geographic, ethnic, and racial variations in the incidence of gestational diabetes mellitus. Diabetes 1985; 34: 8-12.

9. Romundstad LB, Romundstad PR, Sunde A, von Düring V, Skjaerven $\mathrm{R}$, Vatten LJ. Increased risk of placenta previa in pregnancies following IVF/ICSI; a comparison of ART and non-ART pregnancies in the same mother. Hum Reprod. 2006; 21: 2353-8. [CrossRef]

10. Lain, KY, Roberts, JM: Contemporary concepts of the pathogenesis and management of preeclampsia. JAMA 2002; 287: 3183. [CrossRef]

11. ACOG practice bulletin. Diagnosis and management of preeclampsia and eclampsia. Number 33, January 2002. Obstet Gynecol. 2002; 99: 159-67.

12. Bacq Y. Intrahepatic cholestasis of pregnancy. Clin Liver Dis 1999; 3: 1 . [CrossRef]

13. Schieve LA, Ferre C, Peterson HB, Macaluso M, Reynolds MA, Wright VC: Perinatal outcome among singleton infants conceived through assisted reproductive technology in the United States. Obstet Gynecol. 2004 Jun;103(6):1144-53. [CrossRef]

14. Borini A, Bafaro G, Violini F, Bianchi L, Casadio V, Flamigni C. Pregnancies in postmenopausal women over 50 years old in an oocyte donation program. Fertil Steril 1995; 63: 258-61.

15. Blanchettte H. Obstetric performance of patients after oocyte donation. Am J Obstet Gynecol 1993; 168: 1803-7.

16. Porreco RP, Harden L, Gambotto M, Shapiro H: Expectation of pregnancy outcome among mature women. Am J Obstet Gynecol 2005; 192: 38-41. [CrossRef]

17. Keay SD, Liversedge NH, Mathur RS, Jemkins JM. Assisted conception following poor ovarian response to gonadotrophin stimulation. Br J Obstet Gynaecol 1997; 104: 521-7. [CrossRef] 